\title{
POTENSI PENGEMBANGAN KAWASAN TRANSIT ORIENTED DEVELOPMENT (TOD) PADA LINTASAN BRT TRANS JATENG KORIDOR UNGARAN-BAWEN
}

\author{
Denny Apriliyani ${ }^{1}$, Fadjar Hari Mardiansjah ${ }^{1}$ \\ ${ }_{1}$ Program Studi Perencanaan Wilayah dan Kota, Fakultas Teknik, Universitas Diponegoro, Semarang
}

\begin{abstract}
Abstrak
Meningkatnya jumlah penduduk di Kota Semarang mengakibatkan perkembangan kota meluas ke wilayah pinggiran yang salah satunya mengarah ke selatan yaitu Koridor Ungaran-Bawen, Kabupaten Semarang. Hal tersebut mengakibatkan ketergantungan yang tinggi terhadap pusat kota (Kota Semarang) yang dapat dilihat dari tingginya pergerakan penduduk pinggiran ke pusat kota. Pergerakan penduduk wilayah pinggiran Koridor Ungaran-Bawen menuju pusat Kota Semarang diwadahi melalui sistem transportasi publik berupa Bus Rapid Transit (BRT) Trans Jateng Koridor I (Stasiun Tawang-Terminal Bawen) oleh Pemerintah Provinsi Jawa Tengah. Pemberhentian BRT Trans Jateng Koridor I di Koridor Ungaran-Bawen terdiri dari 28 pemberhentian halte bus dan 1 terminal bus yang dapat diklasifikasikan menjadi 9 kawasan transit yang berada pada 4 kecamatan yaitu Kecamatan Ungaran Barat, Kecamatan Ungaran Timur, Kecamatan Bergas, dan Kecamatan Bawen yang masih didominasi dengan lahan non terbangun. Lahan non terbangun tersebut dapat dimanfaatkan dengan menerapkan konsep Transit Oriented Development dengan keragaman penggunaan lahan di sekitar titik pemberhentian yang terintegrasi dengan sistem transportasi kota. Maka, perlu dilakukan penilaian besaran potensi yang dimiliki kawasan transit BRT Trans Jateng Koridor Ungaran-Bawen sebagai kawasan TOD sebelum menerapkannya. Penelitian ini menggunakan metode kuantitatif dengan teknik analisis interpretasi citra dan analisis kebutuhan ruang. Beberapa kawasan transit yang memiliki potensi lebih sebagai kawasan TOD yaitu kawasan transit 1, 3, 4, 5, 6, dan 8, yang mana kawasan transit tersebut memiliki luas ketersediaan lahan kosong yang dapat dimanfaatkan di atas $100.000 \mathrm{~m}^{2}$ yang dapat menyerap/mewadahi penduduk lebih banyak. Strategi pengembangan yang digunakan pada kawasan transit yang memiliki potensi lebih sebagai kawasan TOD yaitu infill site serta kombinasi antara infill site dan new growth area, karena lahan yang akan dikembangkan yaitu lahan kosong. Ketersediaan lahan kosong tersebut dimanfaatkan untuk pembangunan hunian dan sarana publik tambahan sebagai pengembangan kawasan TOD dengan 3 konsep penyediaan yang berbeda, yaitu terintegrasi, kelompok, dan berdiri sendiri.
\end{abstract}

Kata kunci: lahan kosong; pemberhentian; Transit Oriented Development

\begin{abstract}
The population growth of Semarang City triggers peri-urban growth, which in Semarang case is heading to the south, the Ungaran-Bawen Corridor, in Semarang District. Consequently, there is a high dependency of the peripheries to the city center (Semarang City). The communitng pattern request a public transportation system in the form of the Trans Jateng Bus Rapid Transit (BRT) Corridor I (Tawang Station-Bawen Terminal) by the Central Java Provincial Government. The tranist of Trans Jateng BRT Corridor I at Ungaran-Bawen Corridor consists of 28 bus stops and 1 bus terminal which can be classified into 9 transit areas located in 4 sub-districts, namely West Ungaran District, Ungaran Timur District, Bergas District, and Bawen District which are still dominated by non developed land. The non developed land can be utilized by applying the concept of Transit Oriented Development with the diversity of land uses around the transit area which is integrated with the city transportation system. Therefore, it is necessary to assess the potential scale of the Trans Jateng BRT transit areas in Ungaran-Bawen Corridor as TOD area. This research uses quantitative method with image interpretation analysis techniques and analysis of space requirements. Some transit areas that have more potential as TOD areas are transit area 1, 3, 4, 5, 6, and 8, which has wide availability of vacant land that can be utilized above $100.000 \mathrm{~m}^{2}$ which can absorb/accommodate more residents. The development strategy used in the transit areas which have more potential as a TOD areas are infill site and a combination of infill site and new growth area, because the land to be developed is vacant land. The availability of vacant land is used for residential development and additional of public facilities as the development of the TOD areas with 3 different supply concepts, namely integrated, group, and independent.
\end{abstract}

Keywords: transit; Transit Oriented Development; vacant land 


\section{PENDAHULUAN}

Jumlah penduduk Kota Semarang yang semakin meningkat mengakibatkan perkembangan Kota Semarang meluas ke wilayah pinggiran melewati batas administrasinya, salah satunya mengarah ke selatan yaitu Koridor Ungaran-Bawen, Kabupaten Semarang. Pemenuhan kebutuhan dasar di wilayah pinggiran seperti penyediaan perumahan dan infrastruktur memerlukan pembukaan lahan baru, sehingga terjadi konversi lahan pertanian menjadi lahan terbangun. Kawasan perumahan yang terpisah atau tersebar memunculkan ruang-ruang kosong sehingga penggunaan lahan dan penyediaan infrastruktur menjadi tidak efisien karena biaya pengadaan yang mahal dan tidak sebanding dengan jumlah pengguna atau jangkauan daerah pelayanannya (Burchell, Downs, McCann, \& Mukherji, 2005).

Penyediaan infrastruktur yang tidak memadai mengakibatkan ketergantungan yang tinggi terhadap pusat kota yang dapat dilihat dari tingginya pergerakan penduduk pinggiran ke pusat kota, baik untuk bekerja maupun pemenuhan kebutuhan hidup lainnya, di mana pusat kota memiliki fasilitas yang lebih lengkap (Purbo, 2017). Hal tersebut mengakibatkan semakin jauhnya jarak perjalanan yang harus ditempuh ke pusat kota. Pergerakan penduduk pinggiran ke pusat kota terkadang tidak diimbangi dengan sistem transportasi publik yang memadai seperti penempatan titik transit tidak memperhatikan sebaran guna lahan yang merupakan representasi dari zona bangkitan dan tarikan sebagai titik-titik demand (Purbo, 2017) dan tidak didukung dengan fasilitas yang dapat memberikan kemudahan dan kenyamanan bagi masyarakat untuk menuju moda maupun perpindahan antarmoda. Hal tersebut tentu menurunkan minat masyarakat terhadap penggunaan transportasi publik, sehingga mengakibatkan ketergantungan yang tinggi terhadap kendaraan pribadi sebagai cara pemenuhan kebutuhan akan pergerakan. Semakin tingginya pemakaian kendaraan pribadi mengakibatkan sering terjadinya kemacetan lalu lintas pada jam-jam tertentu seperti jam berangkat dan pulang kerja dan dapat menurunkan kualitas lingkungan. Maka, dibutuhkan suatu konsep yang dapat memberikan kehidupan yang nyaman dan kemudahan dalam pemanfaatan waktu untuk sampai ke tujuan.

Konsep Transit Oriented Development (TOD) merupakan bagian dari gerakan pembangunan kota berkelanjutan yang dilatarbelakangi dengan pemikiran bahwa titik-titik transit tidak hanya berfungsi sebagai tempat untuk menaikkan dan menurunkan penumpang, namun juga berfungsi sebagai sebuah tempat berlangsungnya aktivitas perkotaan (Handayeni, 2014). Pola pengembangan yang ditawarkan TOD yaitu keragaman penggunaan lahan di sekitar titik transit dengan kepadatan sedang hingga tinggi dalam skala lokal/kawasan, di mana penduduk yang tinggal di sekitarnya dapat menempuhnya dengan berjalan kaki dari transit utama, sehingga penduduk diberikan kesempatan untuk terhubung ke bagian kota lain dengan sistem transit (Nasri \& Zhang, 2014). Keberhasilan konsep TOD dapat dilihat dari kemampuannya dalam meningkatkan aksesibilitas dan mobilitas sehingga mampu mengurangi ketergantungan terhadap penggunaan kendaraan pribadi dan kemacetan serta meminimalisir penurunan kualitas lingkungan (Handayeni, 2014).

Pergerakan penduduk wilayah pinggiran Koridor Ungaran-Bawen, Kab. Semarang menuju pusat Kota Semarang diwadahi melalui sistem transportasi publik berupa Bus Rapid Transit (BRT) oleh Pemerintah Provinsi Jawa Tengah, yang mana rute tersebut termasuk dalam rute BRT Trans Jateng Koridor I (Stasiun Tawang-Terminal Bawen). Rute tersebut memiliki 79 titik pemberhentian, di mana 50 titik pemberhentian berlokasi di Kota Semarang dan 29 titik pemberhentian berlokasi di Kab. Semarang. Titik-titik pemberhentian di Kabupaten Semarang terdiri dari 28 halte bus dan 1 terminal bus yang kemudian dapat diklasifikasikan menjadi 9 kawasan transit. Titik-titik pemberhentian tersebut melewati Koridor Ungaran-Bawen yang terdiri dari 4 kecamatan yaitu Kec. Ungaran Barat, Kec. Ungaran Timur, Kec. Bergas, dan Kec. Bawen yang masih didominasi dengan lahan non terbangun.

Lahan non terbangun tersebut dapat dimanfaatkan dengan menerapkan konsep TOD, yang mana guna lahan di sekitar titik transit yaitu campuran dan mengintegrasikannya dengan sistem transportasi perkotaan (BRT Trans Jateng Koridor I). Hal tersebut diharapkan dapat membuat penduduk memenuhi kebutuhan hidupnya yang bersifat lokal dengan berjalan kaki atau bersepeda, sehingga mengurangi jarak berpergian yang mana penggunaan transit cenderung untuk bekerja dan pemenuhan kebutuhan yang berada pada skala yang lebih tinggi. Dengan begitu konsep TOD diharapkan juga dapat mengurangi ketergantungan terhadap kendaraan pribadi dan kemacetan serta membantu melindungi kualitas lingkungan. Maka, perlu dilakukan penilaian seberapa besar potensi yang dimiliki kawasan transit BRT Trans Jateng Koridor Ungaran-Bawen sebagai kawasan TOD sebelum menerapkannya. 


\section{KAJIAN LITERATUR}

\subsection{TRANSIT ORIENTED DEVELOPMENT (TOD)}

Konsep Transit Oriented Development (TOD) dilatarbelakangi dengan pemikiran bahwa titik-titik transit (halte, terminal, stasiun, dan sebagainya) tidak hanya berfungsi sebagai tempat untuk menaikkan dan menurunkan penumpang, namun titiktitik transit tersebut juga dapat berfungsi sebagai tempat berlangsungnya aktivitas perkotaan (permukiman, perdagangan dan jasa, perkantoran, pendidikan, dan lainnya) (Handayeni, 2014). Konsep TOD juga diawali dengan konsep aktivitas pergerakan manusia, di mana pergerakan sebagai salah satu aktivitas yang paling banyak dilakukan oleh manusia untuk memenuhi kebutuhan hidupnya, baik dengan moda transportasi, kendaraan pribadi maupun berjalan kaki. Pergerakan tersebut kemudian diwadahi dengan penempatan pusat-pusat aktivitas yang terintegrasi dengan titik-titik transit, sehingga diharapkan dapat meningkatkan pengguna sistem transit (transit ridership) dan mengurangi penggunaan kendaraan pribadi (Handayeni \& Ariastita, 2014).

Karakteristik TOD yaitu bercirikan keragaman penggunaan lahan di sekitar stasiun transit dengan kepadatan sedang hingga tinggi dalam skala lokal/kawasan, di mana penduduk yang tinggal di sekitarnya dapat menempuhnya dengan berjalan kaki dari transit utama dan fasilitas lainnya, sehingga penduduk diberikan kesempatan untuk terhubung ke bagian kota lain dengan sistem transit atau ke seluruh jaringan transit (Nasri \& Zhang, 2014). Peter Calthrope (1993) dalam bukunya The Next American Metropolis mendefinisikan Transit Oriented Development (TOD) sebagai sebuah kawasan penggunaan lahan campuran yang terdiri dari hunian, pertokoan, kantor, ruang terbuka, dan ruang publik yang dapat diakses dengan berjalan kaki dengan rata-rata jarak 2.000 kaki ( $\pm 600 \mathrm{~m}$ atau 10 menit) dari pemberhentian transit dan area pusat komersial, sehingga membuat penduduk dan pekerja mudah untuk berpergian dengan berjalan kaki, bersepeda, atau moda transportasi publik. Penggunaan lahan campuran tersebut diharapkan membuat penduduk di sekitar titik transit dapat memenuhi kebutuhan hidupnya yang bersifat lokal/kawasan dengan berjalan kaki atau bersepeda, sehingga dapat mengurangi jarak berpergian untuk memenuhi kebutuhan hidup, di mana penggunaan transit lebih cenderung untuk bekerja dan berbelanja kebutuhan yang tidak dapat dipenuhi secara lokal, namun pada hirarki/skala yang lebih tinggi.

Menurut Peter Calthrope (1993) dalam buku The Next American Metropolis terdapat beberapa karakteristik penting dalam Transit Oriented Development yaitu sebagai berikut:

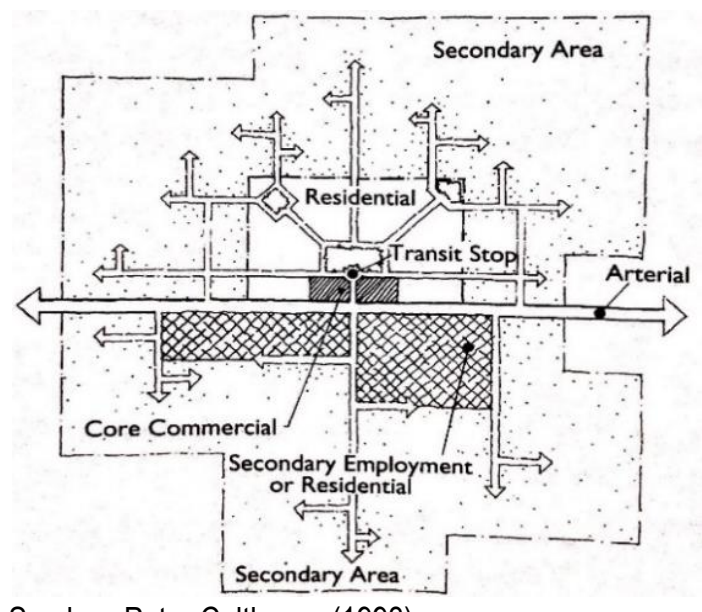

Sumber: Peter Calthrope (1993)

Gambar 1. Ilustri Kawasan Transit Oriented Development

a) Pemberhentian Transit

Pemberhentian transit dapat berupa bandara, pelabuhan, stasiun, terminal, dan halte dengan penggunaan lahan campuran di sekitarnya dengan intensitas kepadatan sedang hingga tinggi. 
b) Area Hunian

Area hunian TOD termasuk perumahan yang berada dalam rata-rata jarak 2.000 kaki atau mewakili jarak berjalan kaki yang nyaman dari area pusat komersial dan pemberhentian transit. Kebutuhan kepadatan hunian terdiri dari berbagai tipe perumahan.

c) Area Pusat Komersial

Setiap TOD harus memiliki area pusat komersial campuran (minimal ritel dan kantor layanan lokal) yang terletak berdekatan dengan pemberhentian transit agar memungkinkan penduduk dan pekerja untuk memenuhi kebutuhan hidupnya di area tersebut dengan berjalan kaki atau bersepeda. Hal tersebut tentunya menguntungkan bagi yang tidak memiliki kendaraan pribadi atau memiliki keterbatasan mobilitas. Bagi yang tetap memilih berkendara menuju toko harus menempuh jarak yang lebih jauh. Sehingga, penggunaan transit cenderung lebih diarahkan untuk bekerja dan berbelanja kebutuhan yang tidak dapat dipenuhi secara lokal, namun pada hirarki yang lebih tinggi.

d) Fungsi Publik

Fungsi publik seperti taman, bangunan publik, dan layanan publik diperlukan untuk melayani penduduk dan pekerja di sekitar titik transit.

e) Area Sekunder

Setiap TOD dapat memiliki area sekunder yang berdekatan dengannya termasuk area di seberang kawasan yang dipisahkan oleh jalan arteri yang tidak lebih jauh 1 mil dari area pusat komersial. Terdapat penggunaan lahan yang tidak sesuai dengan TOD pada area sekunder karena memiliki kepadatan yang lebih rendah. Penggunaan lahan yang membutuhkan pekerja harus terletak tepat di seberang jalan arteri dari pemberhentian transit.

f) Fungsi Lain

Penggunaan lahan yang bergantung pada kendaraan bermotor dan memiliki intensitas jumlah pekerja yang sangat rendah bukanlah penggunaan yang sesuai untuk TOD atau area sekunder karena tidak memiliki jumlah pekerja yang cukup untuk mendukung area pusat komersial dan berkontribusi menciptakan lingkungan pejalan kaki yang sehat, sehingga harus ditempatkan di luar TOD dan area sekunder.

Menurut Peter Calthrope (1993), terdapat 3 jenis strategi kawasan TOD yang terdiri dari:

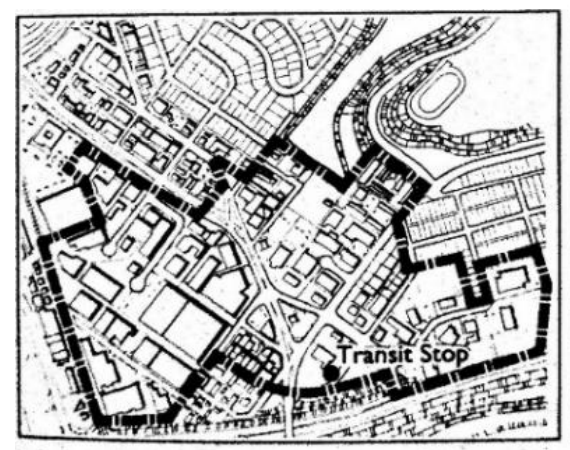

REDEVELOPABLE SITE

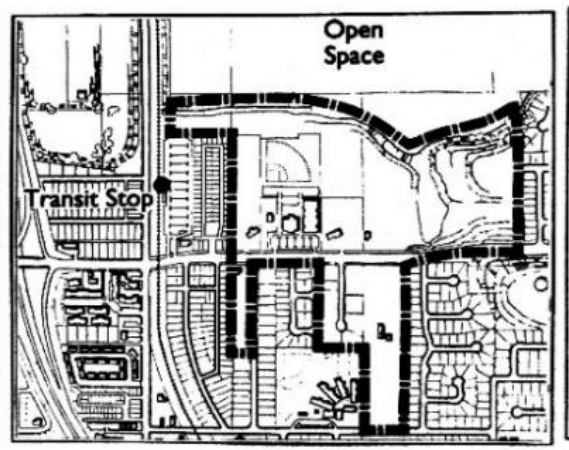

INFILL SITE

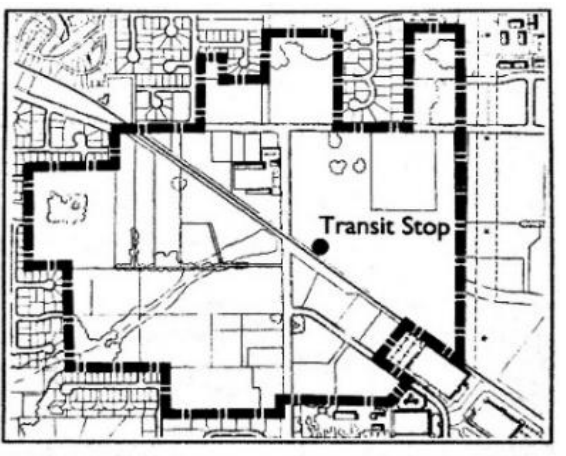

NEW GROWTH AREA

Sumber: Peter Calthrope (1993)

Gambar 2. Strategi Pengembangan Kawasan TOD

a) Redevelopable site, merupakan revitalisasi area dengan penambahan fungsi-fungsi baru dan penataan lingkungan dengan melengkapi layanan fasilitas transit

b) Infill site, merupakan pengembangan daerah kosong/terbengkalai yang umumnya terletak di sekitar pengembangan perkotaan yang ada

c) New growth area, merupakan pembukaan daerah-daerah baru yang luas dan umumnya terletak di daerah perbatasan/pinggir (periphery) kota. 


\subsection{PERENCANAAN LINGKUNGAN PERUMAHAN DI PERKOTAAN}

Berdasarkan SNI 03-1733-2004 tentang Tata Cara Perencanaan Lingkungan Perumahan di Perkotaan, penataan lingkungan merupakan suatu usaha untuk memperbaiki, mengubah, dan mengatur kembali lingkungan tertentu yang sesuai dengan prinsip pemanfaatan ruang secara optimal. Standar Nasional Indonesia Tata Cara Perencanaan Lingkungan Perumahan di Perkotaan merupakan dokumen nasional yang berfungsi sebagai panduan atau kerangka acuan untuk perencanaan, perancangan, penaksiran biaya dan kebutuhan ruang serta pelaksanaan pembangunan perumahan dan permukiman di Indonesia. Penelitian ini menggunakan standar tersebut dalam merencanakan kebutuhan hunian dan sarana publik yang berbasis pada jumlah penduduk dan luas lahan. Terdapat pula kriteria-kriteria dalam menentukan lokasi hunian dan sarana publik yang akan direncanakan.

\section{METODE PENELITIAN}

\subsection{JENIS DAN PENDEKATAN PENELITIAN}

Penelitian ini bertujuan untuk mengetahui seberapa besar potensi yang dimiliki kawasan transit BRT Trans Jateng Koridor Ungaran-Bawen sebagai kawasan TOD. Untuk mencapai tujuan tersebut, penelitian ini menggunakan metode penelitian kuantitatif dengan pendekatan deskriptif. Menurut Sugiyono (2008), metode penelitian kuantitatif diartikan sebagai sebuah metode penelitian yang berlandaskan filsafat positivisme untuk meneliti populasi atau sampel tertentu dengan teknik pengambilan sampel yang umumnya secara random, pengumpulan data menggunakan instrumen penelitian, dan analisis data bersifat kuantitatif/statistik dengan tujuan menguji hipotesis yang telah ditetapkan. Sedangkan pendekatan deskriptif bertujuan untuk menggambarkan objek yang diteliti melalui data yang telah terkumpul sebagaimana adanya tanpa bermaksud membuat kesimpulan yang berlaku umum (Sugiyono, 2008).

\subsection{TEKNIK PENGUMPULAN DATA}

Teknik pengumpulan data penelitian ini dibedakan menjadi pengumpulan data primer dan pengumpulan data sekunder. Teknik pengumpulan data primer yang digunakan dalam penelitian ini yaitu observasi lapangan yang didefinisikan sebagai metode pengumpulan data yang mengamati benda-benda atau objek lain yang mendukung penelitian (Sugiyono, 2008). Dalam penelitian ini observasi lapangan dilakukan untuk mengetahui sebaran sarana publik dan guna lahan pada kawasan transit BRT Trans Jateng Koridor Ungaran-Bawen. Sedangkan teknik pengumpulan data sekunder yang digunakan dalam penelitian ini yaitu telaah dokumen yang didefinisikan sebagai teknik pengumpulan data yang dilakukan dengan cara mengkaji dokumen-dokumen yang biasanya dikeluarkan oleh suatu instansi. Dokumen-dokumen yang akan ditelaah dalam penelitian ini yaitu Rencana Tata Ruang Wilayah Kabupaten Semarang Tahun 2011-2031 yang dikeluarkan oleh BAPPEDA Kabupaten Semarang serta Kabupaten Semarang dalam Angka 2018, Kecamatan Ungaran Timur dalam Angka 2018, Kecamatan Ungaran Barat dalam Angka 2018, Kecamatan Bergas dalam Angka 2018, dan Kecamatan Bawen dalam Angka 2018 yang dikeluarkan oleh BPS Kabupaten Semarang.

\subsection{TEKNIK ANALISIS DATA}

\section{a) Analisis Interpretasi Citra}

Interpretasi atau penafsiran citra penginderaan jauh merupakan kegiatan mengeksplorasi informasi dari citra dengan maksud untuk mengidentifikasi objek yang tergambar pada citra (Purwadhi \& Hardiyanti, 2001). Unsur-unsur pada interpretasi citra yang diperhatikan pada penelitian ini yaitu warna dan bentuk dengan menggunakan aplikasi Sistem Informasi Geografis (SIG) yang erat kaitannya dengan koordinat spasial. Analisis interpretasi citra pada penelitian ini digunakan untuk mengetahui guna lahan dan ketersediaan luas lahan kosong yang dapat dimanfaatkan pada kawasan transit BRT Trans Jateng Koridor Ungaran-Bawen untuk melihat besaran potensi yang dimiliki masing-masing kawasan transit.

b) Analisis Kebutuhan Ruang

Analisis kebutuhan ruang merupakan analisis untuk mengetahui kebutuhan jumlah unit dan luas lahan untuk mewadahi kelompok-kelompok aktivitas yang direncanakan agar dapat berfungsi dan berjalan dengan baik. Pada penelitian ini analisis 
kebutuhan ruang digunakan untuk mengetahui atau merumuskan kebutuhan pengembangan apabila kawasan transit BRT Trans Jateng Koridor Ungaran-Bawen akan dikembangkan sebagai kawasan TOD dengan jumlah penduduk tertentu. Dalam merumuskan kebutuhan pengembangannya, penelitian ini mengacu pada SNI 03-1733-2004 tentang Tata Cara Perencanaan Lingkungan Perumahan di Perkotaan yang berbasis pada jumlah penduduk dan kebutuhan lahan serta kondisi eksisting sekitar (kondisi empiris) yang dapat dijadikan sebagai contoh berdasarkan kondisi-kondisi tertentu. Kebutuhan pengembangan tersebut dilakukan dengan beberapa langkah sebagai berikut:

1. Mendapatkan luas guna lahan termasuk lahan kosong dari interpretasi citra,

2. Mencari luas lahan yang dapat dimanfaatkan dengan luas lahan kosong yang sudah dikurangi untuk alokasi RTH dan sirkulasi dengan penentuan persentase KDB dan RTH berdasarkan kawasan peruntukkan pada RTRW Kabupaten Semarang Tahun 2011-2031,

3. Perhitungan kebutuhan pengembangan berupa sarana publik tambahan untuk penduduk eksisting dengan mengurangi luas lahan yang dapat dimanfaatkan, dan

4. Perhitungan kebutuhan pengembangan berupa tempat tinggal penduduk tambahan (tower) dan sarana publik tambahannya dengan melihat sisa luas lahan yang dapat dimanfaatkan.

\subsection{LOKASI PENELITIAN}

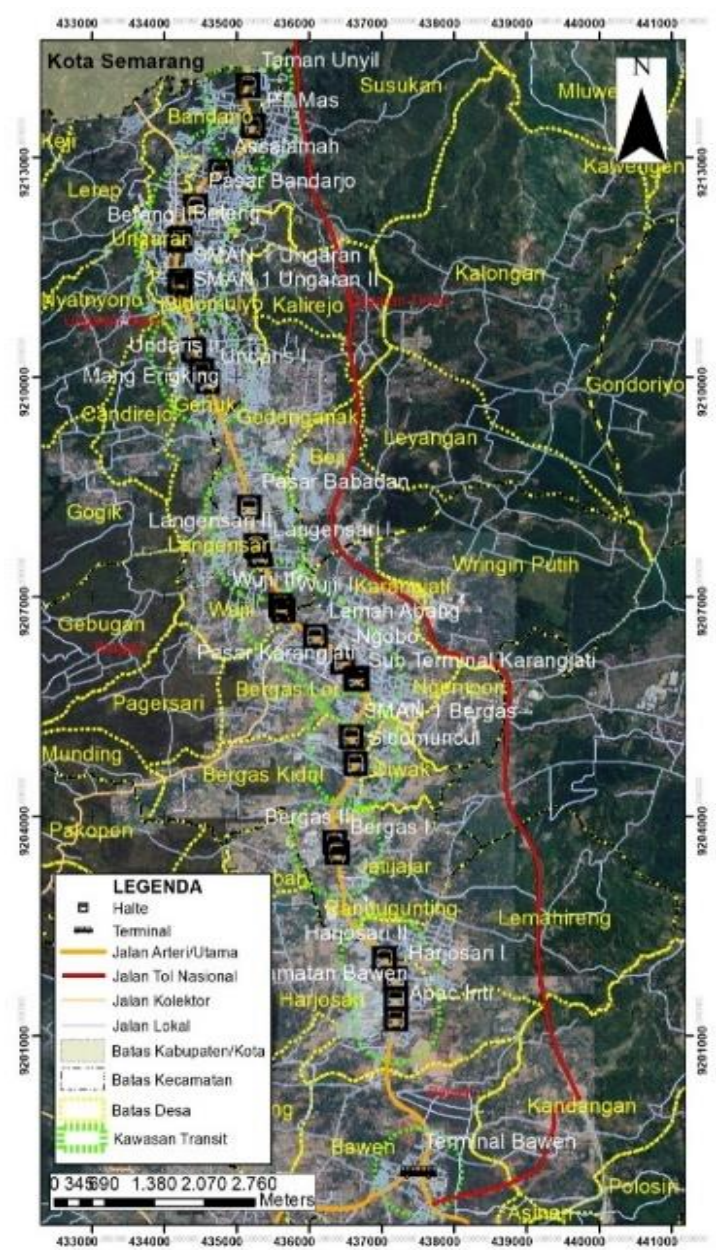

Gambar 3. Peta Kawasan Transit BRT Trans Jateng Koridor Ungaran-Bawen

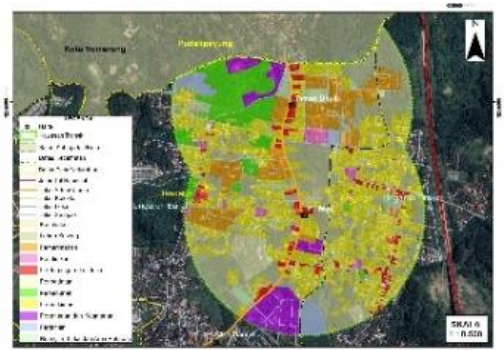

Gambar 4. Peta Guna Lahan Kawasan Transit 1

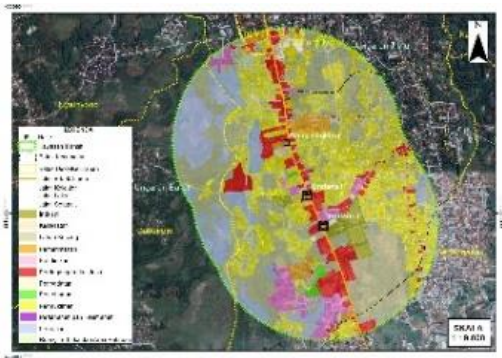

Gambar 6. Peta Guna Lahan Kawasan Transit 3

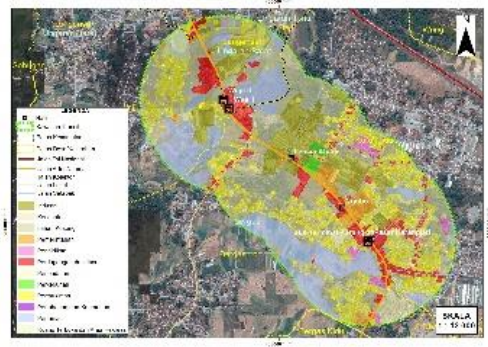

Gambar 8. Peta Guna Lahan Kawasan Transit 5

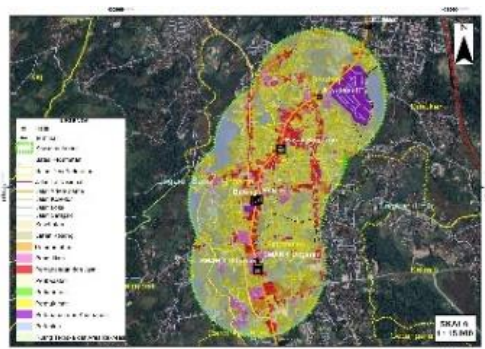

Gambar 5. Peta Guna Lahan Kawasan Transit 2

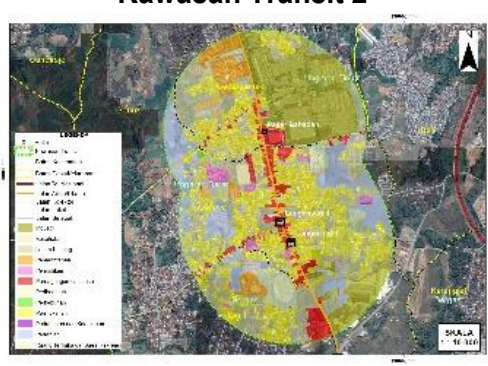

Gambar 7. Peta Guna Lahan Kawasan Transit 4

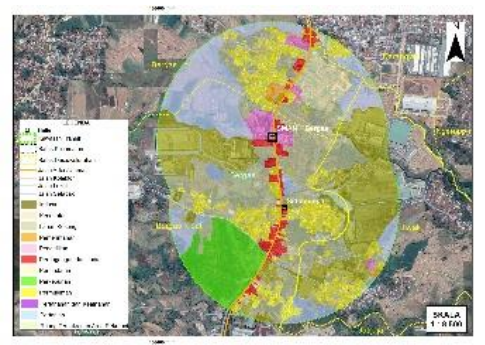

Gambar 9. Peta Guna Lahan Kawasan Transit 6 


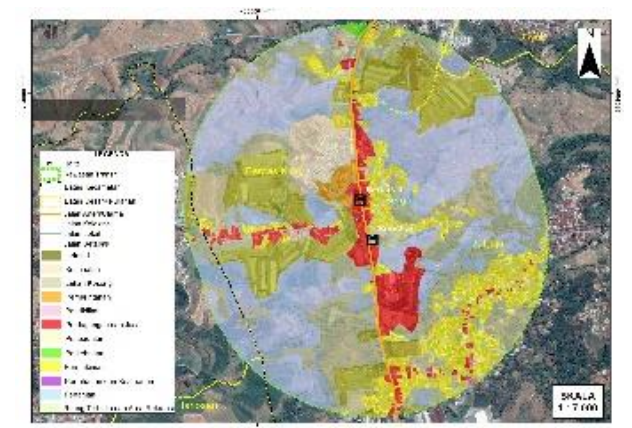

Gambar 10. Peta Guna Lahan Kawasan Transit 7

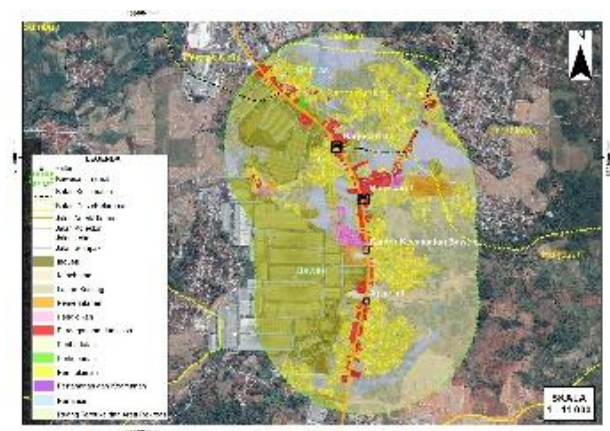

Gambar 11. Peta Guna Lahan Kawasan Transit 8

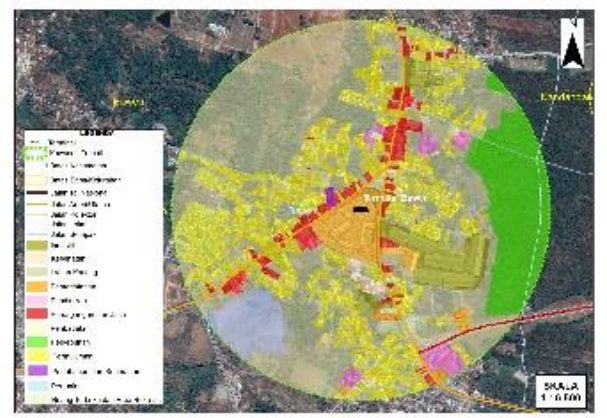

Gambar 12. Peta Guna Lahan Kawasan Transit 9

Terdapat 29 titik pemberhentian BRT Trans Jateng Koridor I (Stasiun Tawang-Terminal Bawen) yang berlokasi di Koridor Ungaran-Bawen, Kabupaten Semarang. Koridor Ungaran-Bawen, Kabupaten Semarang memiliki panjang $\pm 18 \mathrm{~km}$ yang melewati 4 kecamatan yaitu Kecamatan Ungaran Barat, Kecamatan Ungaran Timur, Kecamatan Bergas, dan Kecamatan Bawen. Titik-titik pemberhentian tersebut kemudian di-buffer dengan jarak $600 \mathrm{~m}$ untuk melihat jangkauan kawasan transit. Kawasan transit yang overlapping dengan kawasan transit dan titik pemberhentian di sebelahnya kemudian disatukan menjadi satu kawasan transit, sehingga didapatkan 9 kawasan transit BRT Trans Jateng Koridor Ungaran-Bawen. Untuk lebih jelasnya dapat dilihat pada Gambar 3 sampai dengan Gambar 12 yang bersumber pada Peta Citra Satelit Kawasan Transit BRT Trans Jateng Koridor Ungaran-Bawen (Bakosurtanal, 2014).

\subsection{USULAN KONSEP PENYEDIAAN HUNIAN DAN SARANA PUBLIK TAMBAHAN PADA KAWASAN TRANSIT YANG DIKEMBANGKAN SEBAGAI KAWASAN TOD}

Terdapat 3 konsep penyediaan hunian dan sarana publik tambahan pada kawasan transit yang dikembangkan sebagai kawasan TOD untuk mengoptimalkan ketersediaan lahan yang dapat dimanfaatkan.

\subsubsection{Terintegrasi (Integrated)}

Arti integrasi dalam konsep ini yaitu mengintegrasikan pembangunan hunian dengan sarana publik melalui pendekatan perancangan mixed use building. Mixed use building merupakan upaya pendekatan perancangan yang berusaha menyatukan berbagai aktivitas dan fungsi yang berada di bagian area suatu kota karena luas area terbatas, harga tanah mahal, letak strategis, dan nilai ekonomi tinggi, sehingga terjadi struktur yang kompleks di mana semua kegunaan dan fasilitas saling berkaitan dalam kerangka integrasi yang kuat (Marlina, 2008). Pembangunan hunian tersebut berupa tower dengan 5 lantai, di mana lantai pertama/dasar merupakan sarana publik/pelayanan gabungan dan 4 lantai di atasnya berupa hunian dengan 20 unit/lantai dan luas 80 m²/unit (Lihat Gambar 13). 


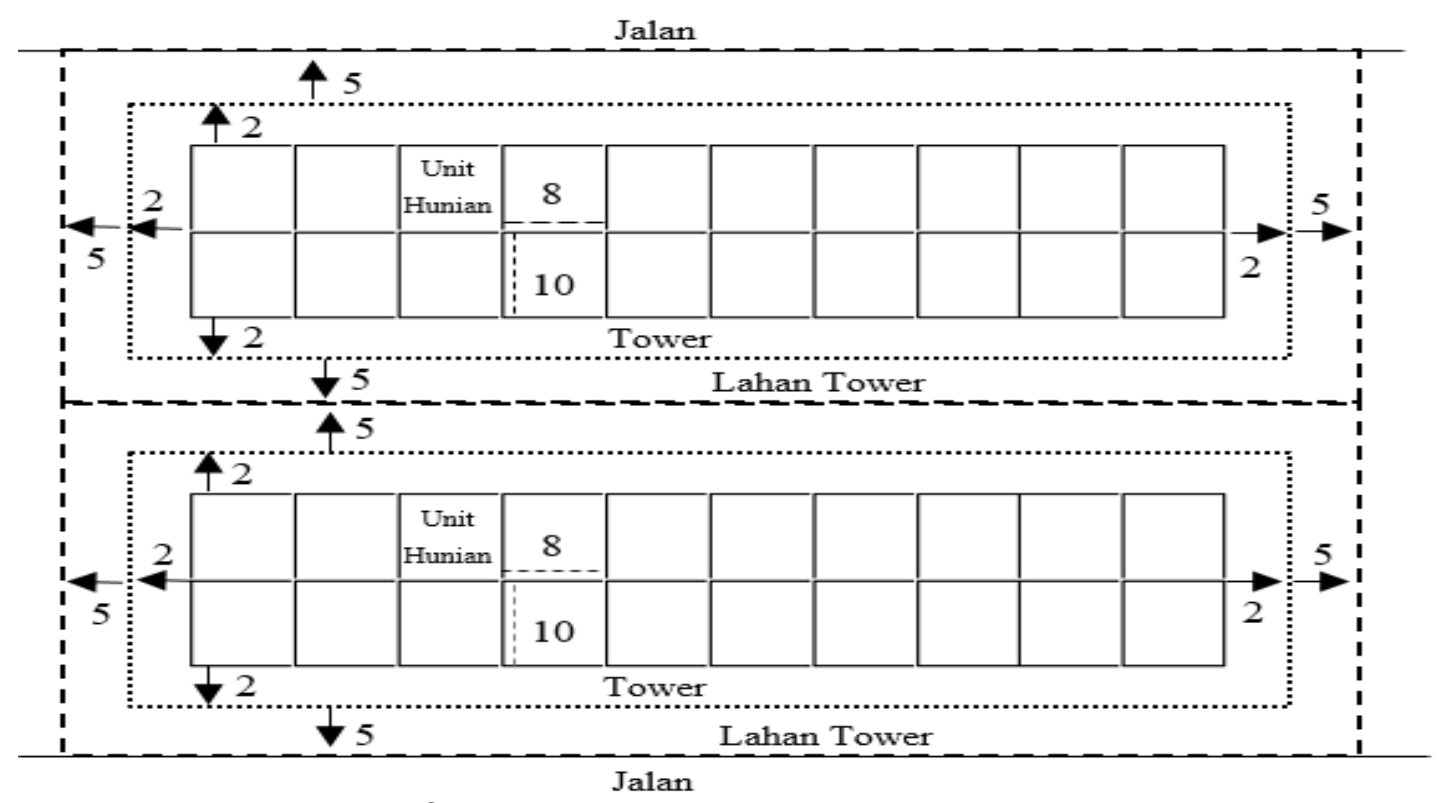

Gambar 13. Rancangan Luasan Lahan Tower

$$
\begin{aligned}
\text { Luas Lahan }= & (5+2+(8 \times 10)+2+5+) \times \\
& (5+2+(10 \times 2)+2+5) \mathrm{m} \\
= & 94 \mathrm{~m} \times 34 \mathrm{~m} \\
= & 3.196 \mathrm{~m}^{2} \rightarrow 3.200 \mathrm{~m}^{2}
\end{aligned}
$$

\begin{tabular}{|c|c|c|}
\hline \multicolumn{3}{|c|}{ Sarana Pemerintahan dan Pelayanan Umum } \\
\hline Balai Warga & $\begin{array}{c}\text { Jumlah } \\
1\end{array}$ & $\begin{array}{c}\text { Kebutuhan Luas Lantai }^{\star} \\
150\end{array}$ \\
\hline \multicolumn{3}{|c|}{ Sarana Pendidikan dan Pembelajaran } \\
\hline Sarana & $\begin{array}{c}\text { Jumlah } \\
1\end{array}$ & $\begin{array}{c}\text { Kebutuhan Luas Lantai* } \\
216\end{array}$ \\
\hline \multicolumn{3}{|c|}{ Sarana Kesehatan } \\
\hline $\begin{array}{l}\text { Posyandu Sarana } \\
\text { Puskesmas Pembantu dan Balai Pengobatan Lingkungan } \\
\text { Apotik }\end{array}$ & $\begin{array}{c}\text { Jumlah } \\
1 \\
1 \\
1 \\
\end{array}$ & $\begin{array}{c}\text { Kebutuhan Luas Lantai* } \\
36 \\
150 \\
120 \\
\end{array}$ \\
\hline \multicolumn{3}{|c|}{ Sarana Peribadatan } \\
\hline Sarana & $\begin{array}{c}\text { Jumlah } \\
1\end{array}$ & $\begin{array}{c}\text { Kebutuhan Luas Lantai* } \\
45\end{array}$ \\
\hline \multicolumn{3}{|c|}{ Sarana Perdagangan dan Niaga } \\
\hline Total Kebutuhan Luas Lantai* & $\begin{array}{c}\text { Jumlah } \\
17\end{array}$ & $\begin{array}{c}\text { Kebutuhan Luas Lantai }^{*} \\
850 \\
1.567\end{array}$ \\
\hline
\end{tabular}

Sarana publik/pelayanan gabungan yang berada pada lantai pertama/dasar tower mendapat alokasi luas lantai sebesar $1.600 \mathrm{~m}^{2}$ yang dapat diisi dengan berbagai jenis sarana publik pada Tabel 1 .

Tabel 1. Sarana Publik/Pelayanan Gabungan pada Lantai Dasar Tower

Sehingga, didapatkan sisa luas lantai sebesar $33 \mathrm{~m}^{2}$ yang dapat dialokasikan untuk toilet. 


\subsubsection{Kelompok (Group)}

Sarana pendidikan dan pembelajaran dikembangkan dengan bentuk kelompok (group), di mana terdapat fasilitas pendidikan yang dapat digunakan secara bersama-sama (sharing facilities), seperti tempat parkir, lapangan, masjid, perpustakaan, atau kantin, sehingga dapat mengoptimalkan ketersediaan lahan kosong. Ketentuan jumlah sarana pendidikan dan pembelajaran dalam grup tersebut maksimal terdiri dari:

a) Model I terdiri dari 5 SMA, 4 SMP, dan 2 SD dengan luas $35.000 \mathrm{~m}^{2}$ yang melihat pada kondisi eksisting pada Tabel 2 .

Tabel 2. Acuan Model I

\begin{tabular}{lcccc}
\multicolumn{1}{c}{ Sekolah } & Luas Lahan $\left(\mathbf{m}^{2}\right)$ & $\begin{array}{c}\text { Jumlah } \\
\text { Rombongan Belajar }\end{array}$ & $\begin{array}{c}\text { Standar Rombongan } \\
\text { Belajar SNI }\end{array}$ & Setara dengan \\
\hline SMAN 4 Semarang & 20.707 & 33 & 6 & 5 SMA \\
SMPN 21 Semarang & 6.888 & 27 & 6 & 4 SMP \\
SDN 2 Srondol Wetan & 7.355 & 12 & 6 & 2 SD \\
Total & $34.950 \rightarrow 35.000$ & & & \\
\hline
\end{tabular}

Sumber: SNI 03-1733-2004 Tentang Tata Cara Perencanaan Lingkungan Perumahan di Perkotaan (2004), Data Pokok Pendidikan

Dasar dan Menengah, Kementerian Pendidikan dan Kebudayaan (2019), dan Hasil Analisis Penyusun (2019)

b) Model II terdiri dari 4 SMP dan 2 SD dengan luas $10.500 \mathrm{~m}^{2}$ yang melihat pada kondisi eksisting pada Tabel 3.

Tabel 3. Acuan Model II

\begin{tabular}{lcccc}
\hline \multicolumn{1}{c}{ Sekolah } & $\begin{array}{c}\text { Luas Lahan } \\
\left(\mathbf{m}^{2}\right)\end{array}$ & $\begin{array}{c}\text { Jumlah } \\
\text { Rombongan Belajar }\end{array}$ & $\begin{array}{c}\text { Standar Rombongan } \\
\text { Belajar dalam SNI }\end{array}$ & Setara dengan \\
\hline SMPN 9 Semarang & 5.252 & 26 & 6 & 4 SMP \\
SDN 2 Karanganyar Gunung & 5.178 & 18 & 6 & 3 SD \\
Total & $10.430 \rightarrow 10.500$ & & \\
Sumber: SNI 03-1733-2004 Tentang Tata Cara Perencanaan Lingkungan Perumahan di Perkotaan (2004), Data Pokok Pendidikan \\
Dasar dan Menengah, Kementerian Pendidikan dan Kebudayaan (2019), dan Hasil Analisis Penyusun (2019)
\end{tabular}

c) Model III terdiri dari 3 SD dengan luas $5.250 \mathrm{~m}^{2}$ yang melihat pada kondisi eksisting pada Tabel 4.

Tabel 4. Acuan Model III

\begin{tabular}{ccccc} 
Sekolah & $\begin{array}{c}\text { Luas Lahan } \\
\left(\mathbf{m}^{2}\right)\end{array}$ & $\begin{array}{c}\text { Jumlah } \\
\text { Rombongan Belajar }\end{array}$ & $\begin{array}{c}\text { Standar Rombongan } \\
\text { Belajar dalam SNI }\end{array}$ & Setara dengan \\
\hline SDN 2 Karanganyar Gunung \\
$\begin{array}{c}\text { Total } \\
\text { T.178 }\end{array}$ & 18 & 6 & 3 SD \\
\hline
\end{tabular}

Sumber: SNI 03-1733-2004 Tentang Tata Cara Perencanaan Lingkungan Perumahan di Perkotaan (2004), Data Pokok Pendidikan

Dasar dan Menengah, Kementerian Pendidikan dan Kebudayaan (2019), dan Hasil Analisis Penyusun (2019)

Namun, apabila jumlah sarana pendidikan dan pembelajaran tidak mendekati ketentuan di atas, maka kebutuhan luas lahan mengikuti ketentuan SNI 03-1733-2004 Tentang Tata Cara Perencanaan Lingkungan Perumahan di Perkotaan.

\subsubsection{Berdiri Sendiri}

Sarana pemerintahan dan pelayanan umum, kesehatan, perdagangan dan niaga serta peribadatan dikembangkan dengan cara berdiri sendiri tanpa memiliki keterikatan dengan sarana publik lainnya, yang mana kebutuhan luas lahan mengikuti ketentuan SNI 03-1733-2004 tentang Tata Cara Perencanaan Lingkungan Perumahan di Perkotaan (lihar Tabel 5). 
Tabel 5. Sarana Publik yang Berdiri Sendiri

\begin{tabular}{lc}
\hline \multicolumn{1}{c}{ Sarana Pemerintahan dan Pelayanan Umum } & Sarana Kesehatan \\
\hline Parkir Umum (RW) & BKIA/Klinik Bersalin \\
Kantor Kelurahan & \\
Pos Pemadam Kebakaran & \\
Parkir Umum (Kelurahan) & \\
Balai Serbaguna/Balai Karang Taruna & \\
\hline \multicolumn{1}{c}{ Sarana Perdagangan dan Niaga } & Sarana Peribadatan \\
\hline Pusat Pertokoan dan Pasar Lingkungan & Masjid Warga \\
& Masjid Kelurahan \\
\hline Sumber: SNI 03-1733-2004 Tentang Tata Cara Perencanaan Lingkungan Perumahan di Perkotaan
\end{tabular}

\subsection{USULAN MODEL DAN PRINSIP-PRINSIP KAWASAN TOD YANG DIKEMBANGKAN}

Terdapat 2 usulan model pengembangan kawasan TOD (Lihat Gambar 14) yang dilihat dari letak ketersediaan lahan kosong yang akan dimanfaatkan yaitu sebagai berikut:

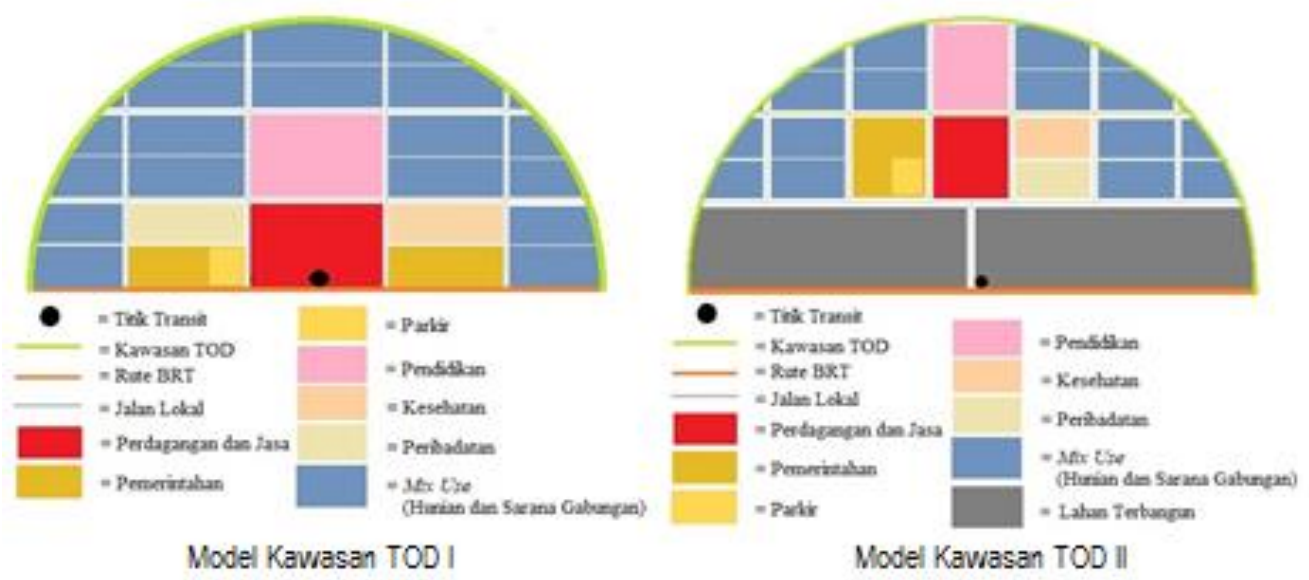

Gambar 14. Model Kawasan TOD I dan Kawasan TOD II

a) Model Kawasan TOD I

Model kawasan ini dikembangkan pada lahan kosong yang berada di pinggir jalan. Sarana publik tambahan dibangun berada dekat dengan titik transit dan tower-tower dibangun mengelilingi sarana publik tambahan tersebut. Hal tersebut tentu membuat penduduk dan pengguna transit dapat menjangkaunya dengan berjalan kaki atau bersepeda.

b) Model Kawasan TOD II

Model kawasan ini dikembangkan pada lahan kosong yang tidak berada langsung di pinggir jalan, namun berada di belakang lahan terbangun. Sarana publik tambahan dibangun di belakang lahan terbangun yang saling berdekatan dan towertower dibangun mengelilingi sarana publik tambahan tersebut. Pada model ini titik transit dihubungkan langsung dengan sarana publik tambahan melalui jalan dan trotoar. Hal tersebut tentunya tetap membuat penduduk dan pengguna transit mudah menjangkau sarana publik tambahan dan tower-tower tersebut dengan berjalan kaki atau dapat diteruskan dengan bersepeda.

Prinsip-prinsip yang dikembangkan pada model kawasan TOD tersebut merujuk pada yang dikemukakan oleh Institute for Transportation and Development Policy (2017) yaitu sebagai berikut: 
a) Berjalan Kaki (Walk)

Kemauan berjalan kaki ditingkatkan dengan menciptakan trotoar yang nyaman seperti dilengkapi dengan pohon penyejuk atau kanopi dan dapat diakses oleh semua kalangan termasuk orang tua, penyandang disabilitas, dan pejalan kaki dengan barang bawaan seperti tongkat, kursi roda, dan kereta bayi dengan lebar trotoar $\pm 2-3 \mathrm{~m}$.

b) Bersepeda (Cycle)

Kegiatan bersepeda didukung dengan menyediakan parkir sepeda yang berada dekat dengan titik pemberhentian.

c) Menghubungkan (Connect)

Sarana publik dan tower dapat dijangkau dengan berjalan kaki dan bersepeda, di mana jalan dan trotoar yang saling terhubung.

d) Angkutan Umum (Transit)

Selain BRT Trans Jateng Koridor I (Stasiun Tawang-Terminal Bawen), kawasan transit ini juga dilewati oleh transportasi publik lainnya seperti angkutan umum. Terdapat feeder yang dapat disediakan di luar kawasan transit, yang mana angkuatan umum tersebut dapat menunggu dan menurunkan penumpang pada tempat parkir yang akan dikembangkan, sehingga layanan transportasi publik saling terhubung atau terintegrasi.

e) Pembauran (Mix)

Kawasan transit dikembangkan dengan penggunaan lahan campuran di sekitar titik pemberhentian. Penggunaan lahan campuran tersebut terdiri dari berbagai sarana publik serta tower yang pada lantai pertama merupukan sarana/layanan gabungan dan lantai di atasnya merupakan hunian.

\section{f) Merapatkan (Compact)}

Berbagai sarana publik dikembangkan dengan saling berdekatan satu sama lain dan tower-tower dikembangkan mengelilingi sarana publik tersebut. Hal tersebut menciptakan waktu dan energi yang lebih sedikit untuk berpergian dari satu aktivitas ke aktivitas lainnya.

\section{HASIL DAN PEMBAHASAN}

\subsection{IDENTIFIKASI KAWASAN POTENSIAL SEBAGAI KAWASAN TOD}

Identifikasi kawasan yang memiliki potensi lebih sebagai kawasan TOD ini dinilai dari luas ketersediaan lahan yang dapat dimanfaatkan. Luas lahan yang dapat dimanfaatkan didapatkan dari sisa luas lahan kosong yang sudah dialokasikan untuk RTH dan sirkulasi dengan penentuan persentase KDB dan RTH berdasarkan kawasan peruntukkan pada RTRW Kabupaten Semarang Tahun 2011-2031. Kawasan yang memiliki potensi lebih sebagai kawasan TOD yaitu sebagai berikut (lihat Tabel 6):

Tabel 6. Kawasan Transit yang Memiliki Potensi Lebih sebagai Kawasan TOD dan Strategi Pengembangannya

\begin{tabular}{clcccc}
\hline $\begin{array}{c}\text { Kawasan } \\
\text { Transit }\end{array}$ & Titik Pemberhentian & $\begin{array}{c}\text { Jumlah } \\
\text { Penduduk } \\
\text { Eksisting } \\
\text { (Tahun 2017) }\end{array}$ & $\begin{array}{c}\text { Luas Ketersediaan } \\
\text { Lahan yang Dapat } \\
\text { Dikembangkan }\left(\mathbf{m}^{2}\right)\end{array}$ & Keterangan & $\begin{array}{c}\text { Startegi } \\
\text { Pengembangan }\end{array}$ \\
\hline 1 & Taman Unyil dan PT Mas & 13.971 & $248.217,32$ & POTENSIAL & $\begin{array}{c}\text { Infill Site dan New } \\
\text { Growth Area }\end{array}$ \\
2 & $\begin{array}{l}\text { Assalamah, Pasar Bandarharjo, } \\
\text { Beteng I, Beteng II, SMAN 1 } \\
\text { Ungaran I, dan SMAN 1 Ungaran II }\end{array}$ & 33.967 & $68.180,46$ & KURANG & POTENSIAL \\
\end{tabular}




\begin{tabular}{|c|c|c|c|c|c|}
\hline $\begin{array}{c}\text { Kawasan } \\
\text { Transit }\end{array}$ & Titik Pemberhentian & $\begin{array}{c}\text { Jumlah } \\
\text { Penduduk } \\
\text { Eksisting } \\
\text { (Tahun 2017) }\end{array}$ & $\begin{array}{l}\text { Luas Ketersediaan } \\
\text { Lahan yang Dapat } \\
\text { Dikembangkan }\left(\mathrm{m}^{2}\right)\end{array}$ & Keterangan & $\begin{array}{c}\text { Startegi } \\
\text { Pengembangan }\end{array}$ \\
\hline 3 & $\begin{array}{l}\text { Mang Engking, Undaris II, dan } \\
\text { Undaris I }\end{array}$ & 28.845 & $250.046,93$ & POTENSIAL & $\begin{array}{l}\text { Infill Site dan New } \\
\text { Growth Area }\end{array}$ \\
\hline 4 & $\begin{array}{l}\text { Pasar Babadan, Langensari II, dan } \\
\text { Langensari I }\end{array}$ & 26.892 & $241.020,87$ & POTENSIAL & Infill Site \\
\hline 5 & $\begin{array}{l}\text { Wujil II, Wujil I, Lemah Abang, } \\
\text { Ngobo, Pasar Karangjati, dan } \\
\text { Subterminal Karangjati }\end{array}$ & 25.734 & $395.782,98$ & POTENSIAL & $\begin{array}{l}\text { Infill Site dan New } \\
\text { Growth Area }\end{array}$ \\
\hline 6 & SMA 1 Bergas dan Sidomuncul & 23.824 & $341.899,22$ & POTENSIAL & $\begin{array}{l}\text { Infill Site dan New } \\
\text { Growth Area }\end{array}$ \\
\hline 7 & Bergas II dan Bergas I & 23.779 & $42.024,64$ & $\begin{array}{l}\text { KURANG } \\
\text { POTENSIAL }\end{array}$ & \\
\hline 8 & $\begin{array}{l}\text { Harjosari II, Harjosari I, Kantor } \\
\text { Kecamatan Bawen, dan Apac Inti }\end{array}$ & 29.525 & $406.560,76$ & POTENSIAL & $\begin{array}{l}\text { Infill Site dan New } \\
\text { Growth Area }\end{array}$ \\
\hline 9 & Terminal Bawen & 13.487 & $83.295,12$ & $\begin{array}{l}\text { KURANG } \\
\text { POTENSIAL }\end{array}$ & \\
\hline
\end{tabular}

Sumber: BPS Kabupaten Semarang (2018), Perhitungan Luas Lahan Kosong yang Sudah Dikurangi Kebutuhan RTH dan Sirkulasi (2019)

Berdasarkan tabel 6, kawasan yang memiliki potensi lebih sebagai kawasan TOD yaitu kawasan dengan luas ketersediaan lahan yang dapat dimanfaatkan di atas $100.000 \mathrm{~m}^{2}$ karena dapat menyerap/mewadahi jumlah penduduk yang lebih banyak, yaitu kawasan transit 1, 3, 4, 5, 6, dan 8. Dari 9 kawasan transit hanya 3 kawasan transit yang kurang memiliki potensi lebih sebagai kawasan TOD karena luas ketersediaan lahan yang dapat dimanfaatkan di bawah $100.000 \mathrm{~m}^{2}$ yang hanya dapat mewadahi jumlah penduduk lebih sedikit, yaitu kawasan transit 2, 7, dan 9. Kawasan-kawasan transit tersebutlah yang akan dinilai lebih lanjut dalam tahap penilaian besaran potensi sebagai kawasan TOD berikutnya.

Dari 3 strategi pengembangan kawasan TOD yang dikemukakan oleh Peter Calthrope (1993), strategi pengembangan yang digunakan pada kawasan transit BRT Trans Jateng Koridor Ungaran-Bawen yang memiliki potensi lebih sebagai kawasan TOD yaitu infill site serta kombinasi antara infill site dan new growth area. Hal tersebut dikarenakan pada penilaian potensi kawasan TOD ini lahan yang akan dikembangkan yaitu hanya memanfaatkan lahan kosong yang belum memiliki bangunan permanen, sehingga tidak merubah kondisi bangunan eksisting sekitar. Infill site digunakan pada kawasan dengan lahan kosong yang tidak terlalu luas sedangkan new growth area pada lahan kosong yang sangat luas.

\subsection{PERHITUNGAN BESARAN POTENSI YANG DIMILIKI KAWASAN POTENSIAL TOD}

Luas lahan kosong yang dapat dimanfaatkan kemudian dikembangkan untuk hunian berupa tower untuk penduduk pada masa depan dan sarana publik tambahan untuk penduduk eksisting dan masa depan. Perhitungan jumlah penduduk tambahan diskenariokan bertempat tinggal pada tower yang terdiri dari 80 unit dengan setiap unit ditempati oleh $1 \mathrm{KK}$ dengan 5 anggota keluarga, sehingga 1 tower dengan luas lahan $3.200 \mathrm{~m}^{2}$ dialokasikan untuk $80 \mathrm{KK}$ atau 400 orang. Perhitungan jumlah penduduk tambahan didapatkan dari luas lahan yang dapat dimanfaatkan yang sudah dikurangi sarana publik tambahan untuk penduduk eksisting, kemudian sisa luas lahan tersebut dialokasikan untuk tempat tinggal penduduk tambahan (tower) dan sarana publik tambahannya. Perkiraan jumlah penduduk masa depan (eksisting + masa depan) sebagai berikut (lihat tabel 7): 
Tabel 7. Besaran Potensi Kawasan Transit BRT Trans Jateng Koridor Ungaran-Bawen sebagai Kawasan TOD

\begin{tabular}{|c|c|c|c|c|c|}
\hline \multirow[b]{2}{*}{$\begin{array}{l}\text { Kawasan } \\
\text { Transit }\end{array}$} & \multirow[b]{2}{*}{ Titik Pemberhentian } & \multirow{2}{*}{$\begin{array}{l}\text { Jumlah } \\
\text { Penduduk } \\
\text { Eksisting } \\
\text { (Tahun 2017) }\end{array}$} & \multirow{2}{*}{$\begin{array}{l}\text { Luas Lahan } \\
\text { yang Dapat } \\
\text { Dimanfaatkan } \\
\left(\mathrm{m}^{2}\right)\end{array}$} & \multicolumn{2}{|c|}{$\begin{array}{c}\text { Alternatif Skenario Pembangunan Hunian } \\
\text { dan Sarana Publik TOD }\end{array}$} \\
\hline & & & & $\begin{array}{l}\text { Jumlah } \\
\text { Penduduk } \\
\text { Tambahan } \\
\text { (Masa Depan) }\end{array}$ & $\begin{array}{c}\text { Perkiraan Jumlah } \\
\text { Penduduk pada Masa } \\
\text { Depan } \\
\text { (Eksisting + Tambahan) }\end{array}$ \\
\hline 1 & Taman Unyil dan PT Mas & 13.971 & $248.217,32$ & 18.000 & 31.971 \\
\hline 2 & $\begin{array}{l}\text { Assalamah, Pasar Bandarharjo, } \\
\text { Beteng I, Beteng II, SMAN } 1 \text { Ungaran } \\
\text { I, dan SMAN } 1 \text { Ungaran II }\end{array}$ & 33.967 & $68.180,46$ & & \\
\hline 3 & $\begin{array}{l}\text { Mang Engking, Undaris II, dan } \\
\text { Undaris I }\end{array}$ & 28.845 & $250.046,93$ & 14.000 & 42.845 \\
\hline 4 & $\begin{array}{l}\text { Pasar Babadan, Langensari II, dan } \\
\text { Langensari I }\end{array}$ & 26.892 & $241.020,87$ & 16.400 & 43.292 \\
\hline 5 & $\begin{array}{l}\text { Wujil II, Wujil I, Lemah Abang, } \\
\text { Ngobo, Pasar Karangjati, dan } \\
\text { Subterminal Karangjati }\end{array}$ & 25.734 & $395.782,98$ & 27.600 & 53.334 \\
\hline 6 & SMA 1 Bergas dan Sidomuncul & 23.824 & $341.899,22$ & 22.400 & 46.224 \\
\hline 7 & Bergas II dan Bergas I & 23.779 & $42.024,64$ & & \\
\hline 8 & $\begin{array}{l}\text { Harjosari II, Harjosari I, Kantor } \\
\text { Kecamatan Bawen, dan Apac Inti }\end{array}$ & 29.525 & $406.560,76$ & 28.400 & 57.925 \\
\hline 9 & Terminal Bawen & 13.487 & $83.295,12$ & & \\
\hline
\end{tabular}

Sumber: BPS Kabupaten Semarang (2018) dan Perhitungan Luas Lahan yang Dapat Dimanfaatkan yang Sudah Dikurangi Sarana Publik Tambahan untuk Penduduk Eksisting, Kemudian Sisanya Dialokasikan untuk Tempat Tinggal Penduduk Tambahan (Tower) dan Sarana Publik Tambahannya (2019)

\subsection{PERUMUSAN KEBUTUHAN PENGEMBANGAN SEBAGAI KAWASAN TOD}

Perkiraan jumlah penduduk masa depan (eksisting dan masa depan) tentunya memerlukan sarana publik untuk memenuhi kebutuhan hidupnya secara lokal. Perumusan kebutuhan pengembangan baik hunian berupa tower dan sarana publik tambahan yaitu sebagai berikut (lihat Tabel 8):

Tabel 8. Kebutuhan Pengembangan Kawasan Transit yang Berpotensi sebagai Kawasan TOD

\begin{tabular}{lr}
\hline \multicolumn{1}{c}{ Kawasan Transit dan Kebutuhan Pengembangan } & $\begin{array}{r}\text { Kebutuhan } \\
\text { Lahan }\left(\mathbf{m}^{2}\right)\end{array}$ \\
\hline A. Kawasan Transit 1 (Taman Unyil dan PT Mas) & 144.000 \\
1.Hunian (45 tower) & 3.700 \\
2.Sarana Pemerintahan (14 parkir umum RW, 1 kantor kelurahan, 2 pos pemadam kebakaran, dan 2 parkir & 75.750 \\
umum kelurahan) & 2.400 \\
3.Sarana Pendidikan dan Pembelajaran (15 SD, 8 SMP, dan 6 SMA) & 20.00 \\
4.Sarana Peribadatan (4 masjid warga) & 245.850 \\
5.Sarana Perdagangan dan Niaga (2 pusat pertokoan dan pasar lingkungan) & Total \\
B.Kawasan Transit 3 (Mang Engking, Undaris II, dan Undaris I) & 112.000 \\
1.Hunian (35 tower) & 7.200 \\
2.Sarana Pemerintahan (18 parkir umum RW, 2 kantor kelurahan, 2 pos pemadam kebakaran, 2 parkir umum & 100.500 \\
kelurahan, dan 2 balai serbaguna/balai karang taruna) & 8.400 \\
3.Sarana Pendidikan dan Pembelajaran (24 SD, 9 SMP, dan 6 SMA) & 20.000 \\
4.Sarana Peribadatan (8 masjid warga dan 1 masjid kelurahan) & 248.100 \\
5.Sarana Perdagangan dan Niaga (2 pusat pertokoan dan pasar lingkungan) & Total \\
C.Kawasan Transit 4 (Pasar Babadan, Langensari II, dan Langensari I) & 131.200
\end{tabular}




\begin{tabular}{lr}
\hline \multicolumn{1}{c}{ Kawasan Transit dan Kebutuhan Pengembangan } & $\begin{array}{r}\text { Kebutuhan } \\
\text { Lahan } \text { ( }^{2} \text { ) }\end{array}$ \\
\hline 2.Sarana Pemerintahan (18 parkir umum RW, 1 kantor kelurahan, 2 pos pemadam kebakaran, dan 2 parkir & 4.200 \\
umum kelurahan) & 89.500 \\
3.Sarana Pendidikan dan Pembelajaran (23 SD, 8 SMP, dan 6 SMA) & 3.000 \\
4.Sarana Kesehatan (1 BKIA/klinik bersalin) & 11.400 \\
5.Sarana Peribadatan (7 masjid warga dan 2 masjid kelurahan) & Total \\
& 239.300 \\
D.Kawasan Transit 5 (Wujil II, Wujil I, Lemah Abang, Ngobo, Pasar Karangjati, dan Subterminal Karangjati) & 220.800 \\
1.Hunian (69 tower) & 3.600 \\
2.Sarana Pemerintahan (22 parkir umum RW, 2 pos pemadam kebakaran, dan 2 parkir umum kelurahan) & 139.000 \\
3.Sarana Pendidikan dan Pembelajaran (29 SD, 8 SMP, dan 12 SMA) & 6.000 \\
4.Sarana Kesehatan (2 BKIA/klinik bersalin) & 14.400 \\
5.Sarana Peribadatan (12 masjid warga dan 2 masjid kelurahan) & 10.000 \\
6.Sarana Perdagangan dan Niaga (1 pusat pertokoan dan pasar lingkungan) & 393.800 \\
& 179.200 \\
E. Kawasan Transit 6 (SMA 1 Bergas dan Sidomuncul) & Total \\
1.Hunian (56 tower) & 5.300 \\
2.Sarana Pemerintahan (19 parkir umum RW, 1 kantor kelurahan, 2 pos pemadam kebakaran, 2 parkir umum & 117.500 \\
kelurahan, dan 1 balai serbaguna/balai karang taruna) & 3.000 \\
3.Sarana Pendidikan dan Pembelajaran (26 SD, 9 SMP, dan 10 SMA) & 15.000 \\
4.Sarana Kesehatan (1 BKIA/klinik bersalin) & 20.000 \\
5.Sarana Peribadatan (13 masjid warga dan 2 masjid kelurahan) & 340.250 \\
6.Sarana Perdagangan dan Niaga (2 pusat pertokoan dan pasar lingkungan) & \\
& 227.200 \\
F. Kawasan Transit 8 (Harjosari II, Harjosari I, Kantor Kecamatan Bawen, dan Apac Inti) & 3.800 \\
1.Hunian (71 tower) & 154.250 \\
2.Sarana Pemerintahan (24 parkir umum RW, 2 pos pemadam kebakaran, dan 2 parkir umum kelurahan) & 3.000 \\
3.Sarana Pendidikan dan Pembelajaran (35 SD, 12 SMP, dan 15 SMA) & 16.200 \\
4.Sarana Kesehatan (1 BKIA/klinik bersalin) & 404.450 \\
5.Sarana Peribadatan (15 masjid warga dan 2 masjid kelurahan) & Total \\
\hline
\end{tabular}

\section{KESIMPULAN}

Beberapa kawasan transit yang memiliki potensi lebih sebagai kawasan TOD yaitu kawasan transit 1, 3, 4, 5, 6, dan 8 , yang mana kawasan transit tersebut memiliki luas ketersediaan lahan yang dapat dimanfaatkan di atas $100.000 \mathrm{~m}^{2}$ yang dapat menyerap/mewadahi jumlah penduduk lebih banyak, sedangkan kawasan transit yang kurang memiliki potensi lebih sebagai kawasan TOD, yaitu kawasan transit 2, 7, dan 9 karena luas ketersediaan lahan yang dapat dimanfaatkan di bawah 100.000 $\mathrm{m}^{2}$ yang hanya dapat mewadahi jumlah penduduk lebih sedikit. Strategi pengembangan yang digunakan pada kawasan transit BRT Trans Jateng Koridor Ungaran-Bawen yang memiliki potensi lebih sebagai kawasan TOD yaitu infill site serta kombinasi antara infill site dan new growth area. Hal tersebut dikarenakan pada penilaian potensi kawasan TOD ini lahan yang akan dikembangkan yaitu hanya memanfaatkan lahan kosong yang belum memiliki bangunan permanen, sehingga tidak merubah kondisi bangunan eksisting sekitar. Strategi pengembangannya infill site digunakan pada lahan kosong yang tidak terlalu luas sedangkan new growth area pada lahan kosong yang sangat luas. Ketersediaan lahan tersebut dikembangkan untuk hunian berupa tower untuk penduduk pada masa depan dan sarana publik tambahan untuk penduduk eksisting dan masa depan sebagai pengembangan kawasan TOD dengan 3 konsep penyediaan yang berbeda, yaitu terintegrasi, kelompok, dan berdiri sendiri. Penelitian ini dapat dimanfaatkan menjadi bahan dalam perumusan arahan pengembangan Koridor Ungaran-Bawen, Kabupaten Semarang dengan konsep TOD. Penelitian ini dapat ditindaklanjuti terkait pola pergerakan dan penyusunan elemen biaya pada masing-masing kawasan transit yang berpotensi sebagai kawasan TOD. 


\section{DAFTAR PUSTAKA}

Badan Pusat Statistik Kabupaten Semarang (2018, Agustus 16). Kabupaten Semarang dalam Angka 2018. Diakses dari https://semarangkab.bps.go.id/publication/2018/08/16/d91ff1f0c2c70645c440fac1/kabupaten-semarang-dalam-angka-2018.html

Badan Pusat Statistik Kabupaten Semarang (2018, September 26). Kecamatan Ungaran Barat dalam Angka 2018. Diakses dari https://semarangkab.bps.go.id/publication/2018/09/26/40a2fe6d6db8aeb9e93ca948/kecamatan-ungaran-barat-dalam-angka2018.html

Badan Pusat Statistik Kabupaten Semarang (2018, September 26). Kecamatan Ungaran Timur dalam Angka 2018. Diakses dari https://semarangkab.bps.go.id/publication/2018/09/26/c5ce7e6e7769c6d8a72da7e4/kecamatan-ungaran-timur-dalam-angka2018.html

Badan Pusat Statistik Kabupaten Semarang (2018, September 26). Kecamatan Bergas dalam Angka 2018. Diakses dari https://semarangkab.bps.go.id/publication/2018/09/26/aa389a6a9fbf6c6048e20e97/kecamatan-bergas-dalam-angka-2018.html

Badan Pusat Statistik Kabupaten Semarang (2018, September 26). Kecamatan Bawen dalam Angka 2018. Diakses dari https://semarangkab.bps.go.id/publication/2018/09/26/50d81188f65c15054555f76e/kecamatan-bawen-dalam-angka-2018.html

Bakosurtanal. (2004) Peta Citra Satelit Kawasan Transit BRT Trans Jateng Koridor Ungaran-Bawen

Burchell, R. W., Downs, A., McCann, B., \& Mukherji, S. (2005). Sprawl Costs Economic Impacts of Unchecked Development. Washingtoon, Covelo, London: Island Press.

Calthrope, P. (1993). The Next American Metropolis. New York: Princeton Architectural Press.

Handayeni, K. D. M. E. (2014). Penerapan TOD (Transit Oriented Development) sebagai Upaya Mewujudkan Transportasi yang Berkelanjutan di Kota Surabaya. Diakses dari https://docplayer.info/49202271-Penerapan-tod-transit-oriented-developmentsebagai-upaya-mewujudkan-transportasi-yang-berkelanjutan-di-kota-surabaya.html

Handayeni, K. D. M. E. \& Ariastita, P. G. (2014). Keberlanjutan Transportasi di Kota Surabaya Melalui Pengembangan Kawasan Berbasis TOD (Transit Oriented Development). Tata Loka, 16, 108-115. Diakses dari https://ejournal2.undip.ac.id/index.php/tataloka/article/view/248/165

Institute for Transportation Development Policy. (2017). TOD Standard. New York: ITDP.

Kementerian Pendidikan dan Kebudayaan. (2019). Data Pokok Pendidikan Dasar dan Menengah. Diakses dari https://dapo.dikdasmen.kemdikbud.go.id/pencarian

Marlina, E. (2008). Panduan Perancangan Bangunan Komersial. Yogyakarta: Andi Offset.

Nasri, A., \& Zhang, L. (2014). The Analysis of Transit-Oriented Development (TOD) in Washington, D.C. and Baltimore Metropolitan Areas. Transport Policy, 32, 172-179. DOI: 10.1016/j.tranpol.2013.12.009.

Peraturan Daerah Kabupaten Semarang Nomor 6 Tahun 2011 Tentang Rencana Tata Ruang Wilayah Kabupaten Semarang Tahun 20112031. Diakses dari http://tataruangpertanahan.com/regulasi/pdf/perda/rtrw/kab/kab_semarang_6_2011.pdf

Purbo, B. (2017). Model Penentuan Lokasi Titik Transit (Studi Kasus: Kota Semarang). Tugas Akhir Tidak Dipublikasi, Departemen Perencanaan Wilayah dan Kota, Universitas Diponegoro, Kota Semarang.

Purwadhi, F. \& Hardiyanti, S. (2001). Interpretasi Citra Digital. Jakarta: Grasindo.

SNI 03-1733-2004 Tentang Tata Cara Perencanaan Lingkungan Perumahan di Perkotaan. Diakses dari http://johannes.lecture.ub.ac.id/files/2012/10/Tata-Cara-Perencanaan-Lingkungan-Perumahan-di-Perkotaan-_-SNI-03-17332004.pdf

Sugiyono. (2008). Metode Penelitian Kuantitatif, Kualitatif, dan R\&D. Bandung: Alfabeta. 